\title{
On the taxonomy of the genus Sacada Walker, 1862 from India, with descriptions of a new genus and two new species (Pyralinae, Pyralidae, Lepidoptera)
}

\author{
Navneet Singh', Jagbir Singh Kirti², Rahul Ranjan ${ }^{1,2}$, \\ Kailash Chandra', Wolfgang Speidel ${ }^{3}$
}

I Zoological Survey of India, M-Block New, Alipore, Kolkata 700 053, West Bengal, India 2 Department of Zoology and Environmental Sciences, Punjabi University, Patiala 147 002, Punjab, India 3 Museum Witt, Tengster, 33, 80796, München, Germany

Corresponding author: Navneet Singh (nsgill007@gmail.com)

Academic editor: Colin Plant | Received 17 February 2020 | Accepted 30 June 2020 | Published 20 August 2020

http://zoobank.org/11F3B46B-E874-4814-B143-46ED071C224C

Citation: Singh N, Kirti JS, Ranjan R, Chandra K, Speidel W (2020) On the taxonomy of the genus Sacada Walker, 1862 from India, with descriptions of a new genus and two new species (Pyralinae, Pyralidae, Lepidoptera). ZooKeys 962: 139-163. https://doi.org/10.3897/zookeys.962.51194

\begin{abstract}
Two new species, Sacada dzonguensis N. Singh, Kirti \& Ranjan, sp. nov. and S. umtasorensis N. Singh, Kirti \& Ranjan, sp. nov., are described from India. Additionally, seven species of the genus Sacada Walker, 1862 are redescribed. A new genus, Pseudosacada N. Singh, Kirti \& Ranjan, gen. nov., is described to accommodate Paravetta flexuosa Snellen, 1890 (presently in Sacada). A new combination is established: Pseudosacada flexuosa (Snellen, 1890), comb. nov. Morphologically, the new genus resembles the genus Sacada and can only be diagnosed by the male genitalia. The diagnostic differences are discussed and illustrated along with adults and external male genitalia of related taxa. A world checklist and a key to the Oriental and Australasian species are provided.
\end{abstract}

\section{Keywords}

distribution, Pseudosacada gen. nov., Sacada dzonguensis sp. nov., S. umtasorensis sp. nov., taxonomic key, world checklist 


\section{Introduction}

The genus Sacada Walker, 1862 is a member of the family Pyralidae Latreille, 1809 and subfamily Pyralinae Latreille, 1809. It was established by monotypy for $S$. decora Walker, 1862 from Sarawak, Borneo. Hampson (1896) broadly discussed the nomenclature of this genus, synonymised several genera (i.e. Sybrida Walker, 1865, Paravetta Moore, 1865, Danaka Moore, 1879, and Xestula Snellen, 1885) with Sacada and studied nine species, which he divided into two distinct sections on the basis of male antennal characters: one group with bipectinate antennae with long branches along three-quarters of their length, and the other group with antennae serrate and fasciculate. Recently, Leraut (2013) revised the generic diagnosis of Sacada by including external genital attributes. The genus is known by 41 species, including 22 from the Oriental region and 10 from India (Nuss et al. 2003-2020).

Herein, two new species are described from India: Sacada dzonguensis N. Singh, Kirti \& Ranjan, sp. nov. (Sikkim) and S. umtasorensis N. Singh, Kirti \& Ranjan, sp. nov. (Meghalaya). In addition, the morphotaxonomy of seven Indian species of Sacada Walker, 1862 is studied. A new genus, Pseudosacada N. Singh, Kirti \& Ranjan, gen. nov., is erected to accommodate Paravetta flexuosa Snellen, 1890 (presently in Sacada), and a new combination is established: Pseudosacada flexuosa (Snellen, 1890), comb. nov. Morphologically, the new genus resembles species of Sacada and can only be diagnosed by the male genitalia. The diagnostic differences are discussed and illustrated along with adults and external male genitalia of related taxa. A world checklist and identification key to the Oriental (23 species) and Australasian (four species) species are also provided. The distribution of species is updated from the publications by Hampson (1896), Yamanaka (1995, 1998), Nuss et al. (2003-2020), Bae et al. (2008), and Sutton et al. (2015) .

\section{Material and methods}

Adult moths were collected using vertical sheet light traps fitted at various localities of India. Collected specimens were euthanized with ethyl acetate vapours in killing jars. The specimens were pinned, stretched, and processed as per standard techniques in lepidopterology. Adult moths were photographed using a Canon EOS 1300D digital SLR camera. The detailed microphotography of external male genitalia was performed under a Leica M165C stereomicroscope attached with a Leica MC190HD camera enabled with a Leica Application Suite. The examined specimens are deposited in the National Zoological Collections, Lepidoptera Section, Zoological Survey of India (ZSI), Kolkata, India.

\section{Abbreviations:}

BMNH Natural History Museum, London, UK (formerly the British Museum of Natural History)

CMNH Carnegie Museum of Natural History, Pittsburgh, Pennsylvania, USA HT Holotype

MGAB Museum of Natural History "Grigore Antipa", Bucharest, Romania 
MNHN Muséum National d'Histoire Naturelle, Paris, France

MWNH Museum Wiesbaden, Wiesbaden, Germany

NHMUK Natural History Museum, London, UK

NZCZSI National Zoological Collections, Zoological Survey of India, Kolkata, India

OUMNH Oxford University Museum of Natural History, Oxford, UK

PT Paratype

RBINS Royal Belgian Institute of Natural Sciences, Brussels, Belgium

RMCA Musée Royal de l'Afrique Centrale, Tervuren, Belgium

RMNH Naturalis Biodiversity Centre [formerly Rijksmuseum van Natuurlijke Historie], Leiden, the Netherlands

TD Type deposited

TL Type locality

ZMHB Museum für Naturkunde der Humboldt-Universität, Berlin, Germany

The collection abbreviations are according to Evenhuis (2020).

\section{Taxonomy}

\section{Genus Sacada Walker, 1862}

Sacada Walker 1862: 136.

Type species. Sacada decora Walker, 1862.

Diagnostic characters. Mostly dark-coloured moths with a slightly variable wing pattern; male antennae typically pectinate (ciliate and toothed in some species). In addition to the narrow forewing with angular edge and the sexual dimorphism with the female being much larger than the male, the genus Sacada is well defined by a number of characters: long legs with tufts of scales, some of which are filiform; thorax with patagia having prominent scales, ending with two brushes; male genitalia with uncus hooded; free valves without process; transtilla modified into elaborate sclerotized structure; juxta well developed; female genitalia with wide anal papillae; very short eighth segment; very short ductus bursae prolonged by a long, ovoid corpus bursae with sclerotisations (Leraut 2013).

Distribution. Cameroon, China, Democratic Republic of the Congo, India, Indonesia, Ivory Coast, Japan, Madagascar, Malawi, Malaysia, Nigeria, Papua New Guinea, Russia, Uganda, Vietnam, Zimbabwe (Nuss et al. 2003-2020); Bhutan, Myanmar, Sri Lanka (Hampson 1896); Nepal (Yamanaka 1995).

\section{Checklist of the genus Sacada}

\section{Genus Sacada Walker, 1862}

$=$ Danaka Moore, 1879

=Datanoides Butler, 1878 
=Kawiella Roepke, 1943

=Marionana Viette, 1953

=Paravetta Moore, 1865

=Sybrida Walker, 1865

=Xestula Snellen, 1885

1 Sacada acutipennis (Strand, 1915) (Aiteta)

TL. Cameroon, Bang Manenguba Mountains

TD. ZMHB

Distribution. Cameroon (Bang Manenguba Mountains)

2 Sacada albioculalis Hampson, 1917

TL. Indonesia, New Guinea, West Papua [Dutch New Guinea], Fak-fak

TD. NHMUK

Distribution. Indonesia (New Guinea, West Papua, Fak-fak)

3 Sacada amoyalis Caradja, 1932

TL. China, Fujian, Xiamen [Amoy]

TD. MGAB

Distribution. China (Fujian, Xiamen [Amoy])

4 Sacada approximans (Leech, 1888) (Datanoides)

TL. Japan, Yokohama

TD. NHMUK

Distribution. Japan (Yokohama), Vietnam (Tam Đảo, Vinh Phuc), Korea

5 Sacada confutsealis Caradja, 1925

TL. China, Fujian, Xiamen [Amoy]

TD. MGAB

Distribution. China (Fujian, Xiamen [Amoy])

6 Sacada constrictalis (Ragonot, 1891) (Sybrida)

TL. India, Upper Assam [Haut-Assam]

TD. ZMHB

Distribution. India (Upper Assam), Borneo

7 Sacada contigua South in Leech \& South, 1901

TL. China, Pu-tsu-fong; Sichuan, Baoxing [Moupin]

TD. NHMUK

Distribution. China (Pu-tsu-fong, Sichuan)

8 Sacada decora Walker, 1862

TL. Malaysia, Borneo, Sarawak

TD. OUMNH 
Distribution. India. Uttarakhand (Kumaon, Dehradun), Sikkim, Nagaland (Chizami), China (Yunnan), Myanmar, Nepal, Thailand, Vietnam, Malaysia (Borneo, Sarawak).

9 Sacada dipenthes Meyrick, 1934

TL. DR Congo [Belgian Congo], Lubumbashi [Elisabethville]

TD. RMCA

Distribution. DR Congo (Lubumbashi [Elisabethville])

10 Sacada discinota (Moore, 1865 [66]) (Paravetta)

TL. India, West Bengal, Darjeeling

TD. NHMUK

Distribution. India (West Bengal, Darjeeling), Nepal

11 Sacada dzonguensis N. Singh, Kirti \& Ranjan, sp. nov.

TL. India, Sikkim, Dzongu

TD. NZCZSI

Distribution. India (Sikkim)

12 Sacada erythropis Hampson, 1917

TL. S. [West] Nigeria, Kwara, Ilorin

TD. NHMUK

Distribution. S. [West] Nigeria (Kwara, Ilorin)

13 Sacada fasciata (Butler, 1878) (Datanoides)

=Xestula miraculosa Snellen, 1885; TL. Russia, Amur river area [pays de la rivière Amour] TD. NHMUK; Distribution. Russia (Amur)

TL. Japan, Yokohama

TD. NHMUK

Distribution. Japan (Yokohama), Russia (Amur), Korea

14 Sacada giovanettae (Marion, 1957) (Danaka)

TL. Ivory Coast

TD. MNHN

Distribution. W. Africa (Ivory Coast)

15 Sacada hoenei Caradja \& Meyrick, 1937

TL. China, Yülingshan

TD. MGAB

Distribution. China (Yunnan)

16 Sacada inordinata (Walker, 1865) (Sybrida)

TL. India, West Bengal, Darjeeling

TD. NHMUK 
Distribution. India (West Bengal, Darjeeling)

17 Sacada madegassalis Viette, 1960

TL. Madagascar

TD. MNHN

Distribution. Madagascar

18 Sacada metaxantha Hampson, 1906

TL. Indonesia, New Guinea, West Papua, Kapaur

TD. NHMUK

Distribution. Indonesia (New Guinea, West Papua, Kapaur)

19 Sacada misakiensis (Shibuya, 1928) (Sybrida)

TL. Japan, Osaka, Misaki

TD. Not known

Distribution. Japan (Osaka, Misaki)

20 Sacada nicopaea Tams, 1941

TL. Uganda

TD. NHMUK

Distribution. Uganda (Kampala)

21 Sacada nigripuncta Hampson, 1906

TL. Indonesia, New Guinea, West Papua, Kapaur

TD. NHMUK

Distribution. Indonesia (New Guinea, West Papua, Kapaur)

22 Sacada nyasana Hampson, 1917

TL. Malawi [British Central Africa], Mt Mulanje

TD. NHMUK

Distribution. Malawi (Mt Mulanje)

23 Sacada olivina Joannis, 1930 [29]

TL. Tonkin [Vietnam], Hoang su phi

TD. MNHN

Distribution. Vietnam (Tonkin, Hoang su phi)

24 Sacada pallescens Hampson, 1896

TL. India, Sikhim, [Sikkim]

TD. NHMUK

Distribution. India (Sikkim), Bhutan, Vietnam, Nepal

25 Sacada papuana Hampson, 1917

TL. Papua New Guinea [British New Guinea], Dinawa 


\section{TD. NHMUK}

Distribution. Papua New Guinea (Dinawa)

26 Sacada paraxantha Meyrick, 1936

TL. Democratic Republic of the Congo [Belgian Congo], Lubumbashi [Elisabethville] TD. RMCA

Distribution. Democratic Republic of the Congo (Lubumbashi)

27 Sacada paulianalis (Viette, 1953) (Marionana)

=Marionana vinolentalis Viette, 1960; TL. Madagascar, Route d'Anosibé; TD. MNHN;

Distribution. Madagascar

TL. Madagascar, Périnet, forêt du domaine de l'Est

TD. MNHN

Distribution. Madagascar

28 Sacada peltobathra Meyrick, 1938

TL. Indonesia, Java, Mt Guntur

TD. NHMUK

Distribution. Indonesia (Sumatra, Java. Mt Guntur)

29 Sacada pusilla Hering, 1901

TL. Indonesia, Sumatra

TD. Not known

Distribution. Indonesia (Sumatra)

30 Sacada pyraliformis (Moore, 1879) (Danaka)

TL. India, West Bengal, Darjiling

TD. ZMHB

Distribution. India (West Bengal, Darjeeling), Nepal, Myanmar, Thailand

31 Sacada ragonotalis (Snellen, 1892) (Sybrida)

= Kawiella testacea Roepke, 1943; TL. Indonesia, W Java, Perbawattee TD. RMNH;

Distribution. Indonesia (Java)

TL. Indonesia, Java

TD. Syntypes in MWNH

Distribution. Indonesia (Sumatra, Java, Bali), Borneo

32 Sacada rhodinalis Hampson, 1906

TL. Zimbabwe, Mashonaland

TD. NHMUK

Distribution. Zimbabwe (Mashonaland)

33 Sacada rhyacophila (Ghesquière, 1942) (Danaka)

TL. DR of the Congo [Congo belge], Equateur, Bolombo 
TD. RMCA

Distribution. Democratic Republic of the Congo

34 Sacada rosealis Hampson, 1906

TL. Zimbabwe [Mashonaland], Harare [Salisbury]

TD. NHMUK

Distribution. Zimbabwe (Mashonaland, Harare)

35 Sacada rubralis Holland, 1900

TL. Indonesia, Maluku, Buru

TD. $\mathrm{CMNH}$

Distribution. Indonesia (Maluku, Buru)

36 Sacada rufina Hampson, 1896

TL. India, Maharashtra, Mumbai [Bombay]

TD. NHMUK

Distribution. India (Maharashtra, Mumbai [Bombay])

37 Sacada sikkima (Moore, 1879) (Paravetta)

TL. India, West Bengal, Darjeeling

TD. Syntype in NHMUK

Distribution. India (West Bengal, Darjeeling), Nepal

38 Sacada szetschwanalis Caradja, 1927

TL. China, Sichuan (Kwanhsien Talbo)

TD. MGAB

Distribution. China (Sichuan)

39 Sacada tonsealis Roepke, 1938

TL. Indonesia, northern Sulawesi

TD. RBINS

Distribution. Indonesia (North Celebes [Sulawesi]), Borneo

40 Sacada umtasorensis N. Singh, Kirti \& Ranjan, sp. nov.

TL. India, Meghalaya, Umtasor

TD. NZCZSI

Distribution. India (Meghalaya)

41 Sacada unilinealis Hampson, 1896

TL. India, Sikhim [Sikkim]

TD. NHMUK

Distribution. India (Sikkim) 
42 Sacada viridalis Hampson, 1917

TL. Cameroon, Ja R[iver], Bitje

TD. NHMUK

Distribution. Cameroon

\section{Sacada sikkima (Moore, 1879)}

Figs 1, 2, 19, 20

Paravetta sikkima Moore 1879: 70.

Description. Male, wingspan $28 \mathrm{~mm}$ (Figs 1, 2). Adult dark purplish fuscous. Forewing with a dark rufous rectangular patch near base, touching antemedial line which is highly angled in interno-median interspace; postmedial line pale, sinuous, outwardly oblique from costa to vein $M_{2}$, then very oblique to inner margin; area between antemedial and postmedial line paler and beyond postmedial line darker. Hindwing pale brown; a pale, slightly waved submarginal line crossed by a dark streak at vein $\mathrm{Cu}_{1}$. Male genitalia (Figs 19, 20). Uncus broad with flaps on lateral side, gnathos reaching up to tip of uncus, tip hooked; valva simple, without any process; tegumen simple; transtilla broad with sclerotised, bifid process originating medially; juxta in form of two long arms, broad medially, spined apically; saccus deeply U-shaped; vesica membranous with fine scobination, without any cornuti.

Diagnosis. Sacada sikkima is externally similar to S. constrictalis from India, but differs by its larger size, and in having the postmedial line outwardly oblique from the costa to vein $\mathrm{M}_{2}$, whereas, in $S$. constrictalis the postmedial lines is almost straight. In the male genitalia (Figs 19, 20), the transtillar processes are longer; the juxta is larger.

Type material examined. Lectotype (Fig. 2): BMNH (E) 1626971, male, Darjeeling, Moore coll. 94-106, Paravetta sikkima Moore, det. M. Shaffer, 1976.

Other material examined. India, Sikkim: 1 Oे, Dodak, 24.ix.2014, leg. R. Ranjan (Coll. NZCZSI). India, Uttarakhand: 1 ô, Dehradun, 22.v.2014, leg. R. Ranjan (Coll. NZCZSI). India, Meghalaya: $1 \hat{\jmath}$, Umtasor, 15.ix.2014, leg. R. Ranjan (Coll. NZCZSI). India, Mizoram: 1 ○े, Mamit, 08.ix.2016, leg. R. Ranjan (Coll. NZCZSI); India, Arunachal Pradesh: 1 d , Dibang valley, Italin, 26.x.2017, leg. R. Ranjan (Coll. NZCZSI).

\section{Sacada constrictalis (Ragonot, 1891)}

Figs 3, 21, 22

Sybrida constrictalis Ragonot 1891: 75-76, pl. 8 fig. 10.

Description. Male, wingspan $24 \mathrm{~mm}$ (Fig. 3). Adult dark purplish fuscous. Forewing with a dark rufous rectangular patch near base, touching antemedial line, which is highly angled in interno-median interspace; postmedial line pale, sinuous, nearly 
orthogonal from costa to vein $\mathrm{M}_{2}$, then very oblique to inner margin; area between antemedial and postmedial line paler; discocellular with two specks, outer one darker. Hindwing pale fuscous, submarginal line pale, slightly waved, crossed by a dark streak at vein $\mathrm{Cu}_{1}$. Cilia of both wings ochreous, with two black lines passing through them. Male genitalia (Figs 21, 22). Uncus broad with flaps on lateral side; gnathos with tip hooked; valva simple, without any process; tegumen simple; transtilla broad and sclerotised, bifid process originating medially; juxta broad with a vertical incision from tip to base, forming two arms, spined apically; saccus U-shaped; vesica membranous with fine scobination, without any cornuti.

Diagnosis. Provided with the diagnosis of S. sikkima.

Material examined. India, Meghalaya: $3 \AA$, Cherrapunji, 04.ix.2014, leg. R. Ranjan (Coll. NZCZSI); 1 $\hat{\jmath}$, Umtasor, 15.ix.2014, leg. R. Ranjan (Coll. NZCZSI).

\section{Sacada discinota (Moore, 1865)}

Figs 4-6, 23, 24

Paravetta discinota Moore 1865: 814, pl. 43 fig. 3.

Description. Male, wingspan $32 \mathrm{~mm}$ (Figs 4-6). Forewing pale brown, a pale antemedial line, acutely angled in interno-median interspace with fuscous brown rectangular patch on its inner area and a similar postmedial line acutely angled at vein $\mathrm{M}_{1}$ (in one Golitar (Sikkim) specimen, angled antemedial line touches postmedial line at vein $\mathrm{Cu}_{2}$; Fig. 4); area between two lines pale brown with oblique ferruginous reniform spot. Hindwing pale; traces of a waved submarginal line; underside paler with similar markings. Thorax with long, brown patagia. Male genitalia (Figs 23, 24). Uncus broad, laterally folded, apically rounded; gnathos short and well developed, reaching up to midst of uncus, tip hooked; valva simple, without any process; tegumen broad; transtilla broad, a sclerotised flap-like process originating medially; juxta long, broad, slightly constricted at apex; vinculum Ushaped; aedeagus long, sclerotized carinal plate with numerous spikes; vesica membranous with fine scobination, cornuti absent.

Diagnosis. Among the Sacada species reported from India, S. discinota is externally similar to $S$. sikkima and $S$. constrictalis due to the highly angled antemedial and postmedial lines, but it is distinct from both of these congeners by its paler hindwings.

Type material examined. Lectotype (Fig. 6): BMNH (E) 1627006, male, Darjeeling, Moore Coll. 94-106, Paravetta discinota Moore, det. M. Shaffer, 1976.

Other material examined. India, Sikkim: 4 O , Golitar, 20.ix.2014, leg. R. Ran-

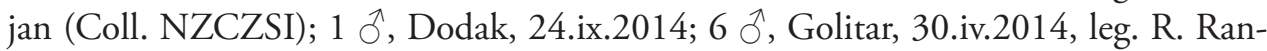
jan (Coll. NZCZSI); 3 ô, Golitar, 19.ix.2014, leg. R. Ranjan (Coll. NZCZSI); 1 ô, Chungthang, 26.iv.2014, leg. R. Ranjan (Coll. NZCZSI). 


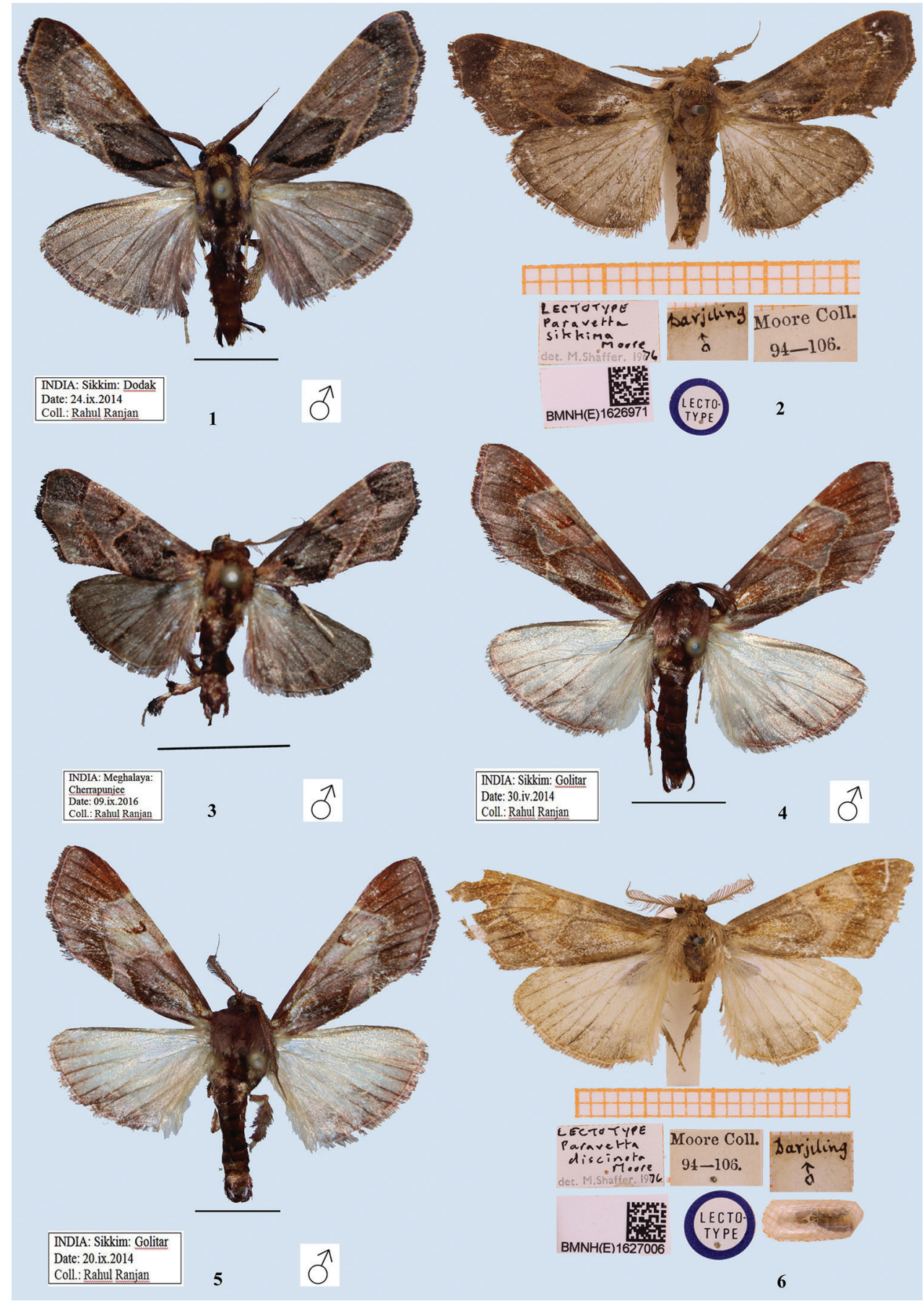

Figures I-6. Adults of Sacada spp. I S. sikkima (Moore) (male), India 2 S. sikkima (Moore) (male), lectotype, Darjeeling, India $3 S$. constrictalis (Ragonot) (male), India 4, 5 S. discinota (Moore) (male), India 6 S. discinota (Moore) (male), lectotype, Darjeeling, India. Scale bars: $5 \mathrm{~mm}$ (I); $12.7 \mathrm{~mm}$ (3-5). 
Remark. The lectotype is hereby formally designated.

\section{Sacada unilinealis Hampson, 1896}

Figs 7, 8, 25, 26

Sacada unilinealis Hampson 1896: 170.

Description. Male, wingspan 32-34 mm (Figs 7, 8). Adult pale rufous, speckled with fuscous; forewing pale brownish pink; basal and apical area of costa rufous; forewing with two black specks (lower one large, giving appearance of a spot) conjoined by a narrow bar; traces of evenly curved postmedial line, with area beyond it darker. Hindwing pale, with faint traces of a curved submarginal line. Cilia of both wings dark rufous. Blackish fringe of hair on fore and mid tibiae. Male genitalia (Figs 25, 26) with uncus short, broad with flaps on lateral side; gnathos well developed reaching to uncus, tip hooked; valva broad, simple, without any process; tegumen simple; transtilla with a sclerotised process arising medially; juxta double, each broad at base, apically pointed and sclerotised, concave on inner edge, convex on outer edge; saccus long, broadly U-shaped; vesica membranous with fine scobination, without any cornuti.

Diagnosis. Sacada unilinealis is an unmistakable species due to the weak markings and almost uniform colour of the fore and hindwings.

Type material examined. Holotype (Fig. 8): BMNH (E) 1627040, male, Sikkim, O. Möller, 89, collection H. J. Elwes, Sacada unilinealis Hampson.

Other material examined. India, Sikkim: 1 O , Dodak, 09.ix.2016, leg. R. Ranjan (Coll. NZCZSI)

\section{Sacada inordinata (Walker, 1865)}

Fig. 9

Sybrida inordinata Walker 1865: 466.

Description. Adults are rufous. Forewing with diffused a ferruginous patch in interno-median interspace; a medial line approximately right angled, reaching at vein $\mathrm{Cu}_{2}$; postmedial line obliquely straight with some ferruginous beyond it, merged the medial line at $\mathrm{Cu}_{2}$ and touching the inner margin; a ferruginous line on discocellular; termen smoothly curved. Hindwing browner, with traces of dark postmedial line.

Diagnosis. Provided with the following species.

Type material examined. Holotype, male, BMNH (E) 1626174, Sybrida inordinata, Darjeeling, 60-15 E. I. C. [East India Company]. 


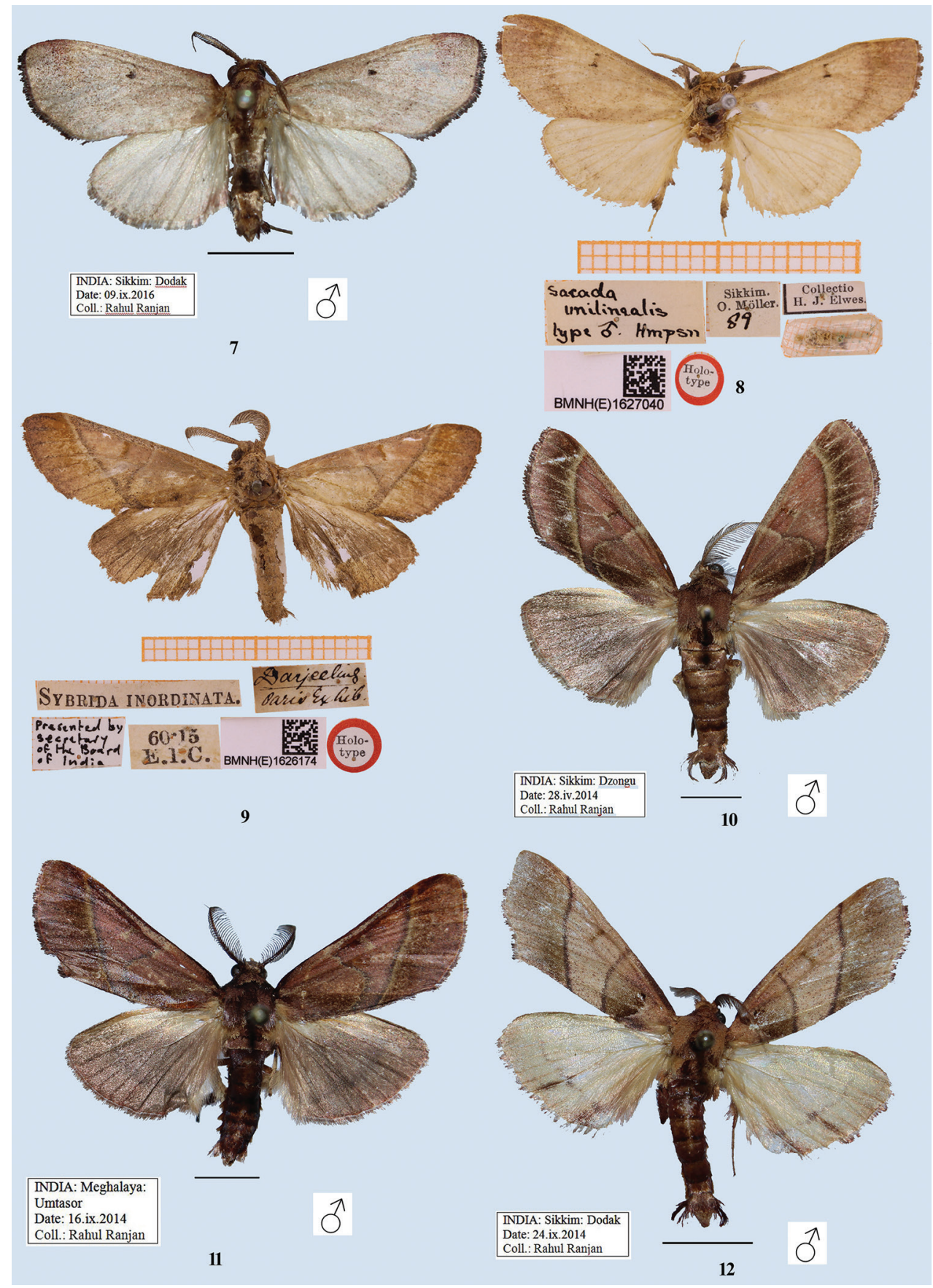

Figures 7-12. Adults of Sacada spp. 7 S. unilinealis Hampson (male), India 8 S. unilinealis Hampson (male), holotype, Sikkim, India 9 S. inordinata (Walker) (male), holotype, Darjeeling, India 10 S. dzonguensis, sp. nov. (male), India. II S. umtasorensis, sp. nov. (male), India I 2 S. pallescens Hampson (male), India. Scale bars: $5 \mathrm{~mm}(\mathbf{7}, \mathbf{I} \mathbf{0}, \mathbf{I})$; $12.7 \mathrm{~mm}(\mathbf{I})$. 


\section{Sacada dzonguensis N. Singh, Kirti \& Ranjan, sp. nov.}

http://zoobank.org/E2147930-463E-4DF6-ABD3-A500CC3FFA88

Figs 10, 27, 28

Description. Male, wingspan $36 \mathrm{~mm}$ (Fig. 10). Rufous brown. Forewing with a medial fuscous line outwardly oblique from costa to vein $\mathrm{Cu}_{2}$, slightly indented in cell, at $\mathrm{Cu}_{2}$ rounded inwardly to meet inner margin; a dark streak on discocellular; a postmedial fuscous line, inwardly oblique from radial veins; inner area of antemedial and outer area of postmedial lines bordered with ochreous scales; a broad fuscous band beyond postmedial line, veins on it paler; inner area dark brownish; a fine marginal line, cilia brownish; underside rufous with inner area ochreous. Hindwing pale fuscous with rufous tinge; traces of diffuse, postmedial fuscous line; a fine marginal line present; underside rufous. Male genitalia (Figs 27, 28): uncus hooded with baso-lateral flaps; gnathos curved distally, tip pointed and hooked, broadened below tip; valva simple; transtilla broad and curved distally; juxta broad at base, mediolateral area constricted, bifid apically: both arms (spikes) bearing small spines; vinculum U-shaped; aedeagus apex with multiple rows of small spines; base of vesica densely scobinated and the scobination gradually becomes sparse towards distal end.

Diagnosis. Sacada dzonguensis sp. nov. is most similar to S. inordinata (Fig. 9), but the forewing has the antemedial and postmedial lines clearly separated, and there is a broad fuscous band beyond the postmedial line, whereas in $S$. inordinata both lines are fused from vein $\mathrm{Cu}_{2}$ to the inner margin, and the postmedial fuscous band is absent (but with traces of ferruginous).

Type material. Holotype, male. India, Sikkim: Dzongu, 28.iv.2014, leg. R. Ranjan (Coll. NZCZSI).

Etymology. The species is named after its type locality, Dzongu, Sikkim, India.

\section{Sacada umtasorensis N. Singh, Kirti \& Ranjan, sp. nov.}

http://zoobank.org/AE3EC692-2759-4260-829C-C01F12F03392

Figs 11, 29, 30

Description. Male, wingspan $30 \mathrm{~mm}$ (Fig. 11). Rufous brown. Forewing with a sinuous medial fuscous line outwardly oblique from costa to vein $\mathrm{Cu}_{2}$, then broadly and inwardly rounded to meet inner margin; a band of paler scales on discocellular; postmedial fuscous line, slightly curved, inwardly oblique from costa to inner margin; inner area of medial line and outer area of postmedial line bordered with ochreous scales; a broad ferruginous band beyond postmedial line; a fine marginal line, cilia brownish; underside rufous with inner area ochreous. Hindwing pale fuscous with rufous tinge; traces of diffused, postmedial fuscous line; a fine marginal line present; underside rufous. Male genitalia (Figs 29, 30): uncus hooded with baso-lateral flaps; gnathos curved distally, hooked, tip pointed, broadened before tip; valva simple; transtilla broad with two apical, small thumb-like processes; juxta narrow, mediolateral 


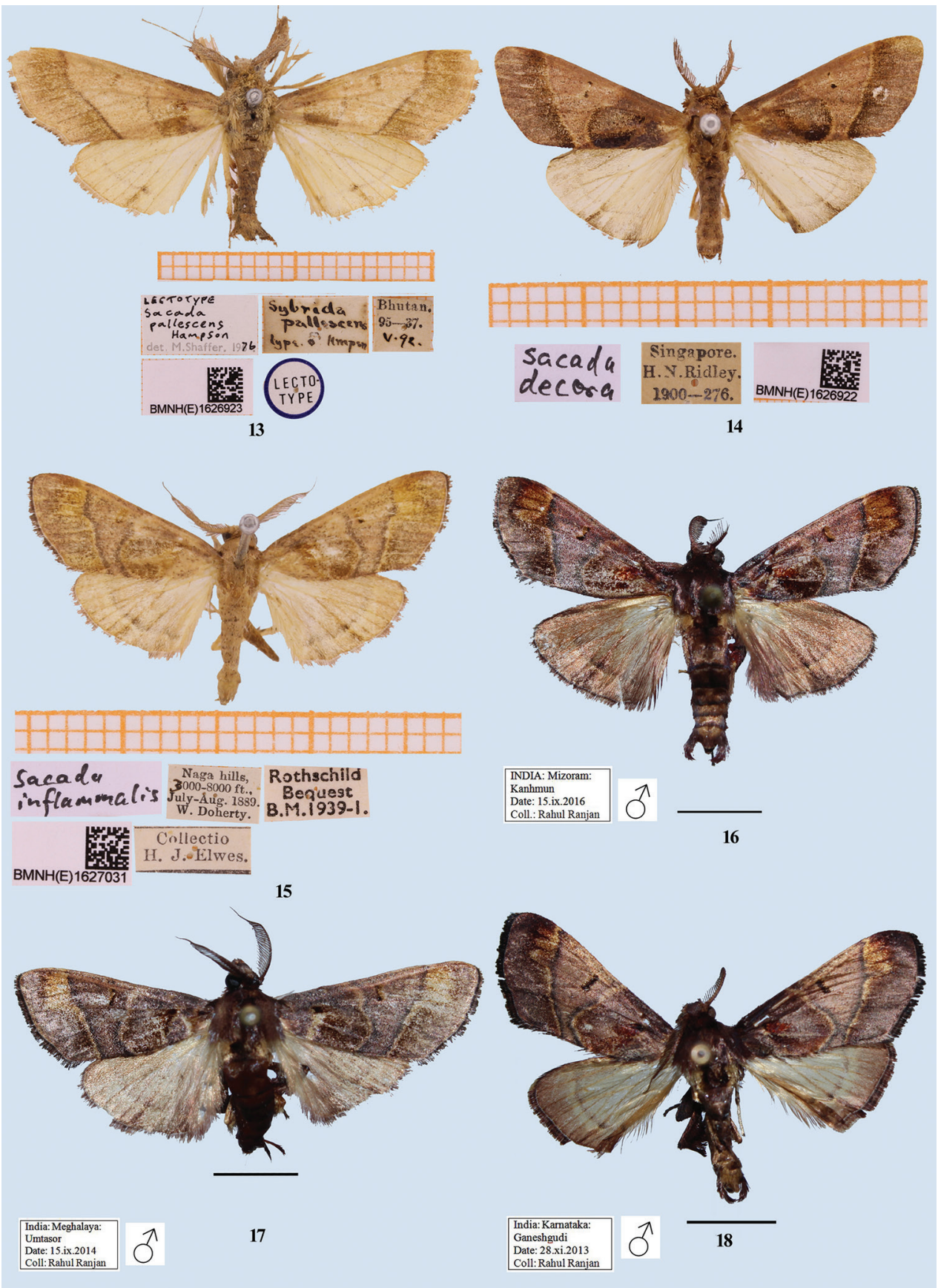

Figures I3-18. Adults of Sacada and Pseudosacada spp. I3 S. pallescens Hampson (male), lectotype, Bhu$\tan 14$ S. decora Walker, Singapore I5 Pseudosacada flexuosa (Snellen) (= Sybrida inflammealis Ragonot), India 16 P. flexuosa (Snellen) (male), Kanhmun, Mizoram, India 17 P. flexuosa (Snellen) (male), Umtasor, Meghalaya, India 18 P. flexuosa (Snellen) (male), Ganeshgudi, Karnataka, India. Scale bars: 5 mm (I6-I 8). 
area constricted, bifid apically with both the arms bearing spikes; vinculum U-shaped; aedeagus apex with single row of small spines; base of vesica densely scobinated and the scobination gradually becomes sparse towards apex.

Diagnosis. Sacada umtasorensis sp. nov., distributed in Meghalaya is most closely similar to its allopatric relative $S$. dzonguensis sp. nov., (distributed in Sikkim) (Fig. 10), but it is distinct by the oblique postmedial line from costa to inner margin, whereas in $S$. $d z o n g$ uensis, the postmedial line is straight from the costa to the radial vein and then oblique to the inner margin. In the male genitalia of S. umtasorensis (Figs 29, 30), the juxta is narrow with the two apical lobes exhibiting more spines, and the aedeagus apex has a single row of small spines, whereas in $S$. dzonguensis (Figs 27, 28), the juxta is broad, the apical lobes have fewer spines, and the aedeagus apex exhibits multiple rows of small spines.

Type material. Holotype, male. India, Meghalaya: Umtasor, 16.ix.2014, leg. R. Ranjan (Coll. NZCZSI).

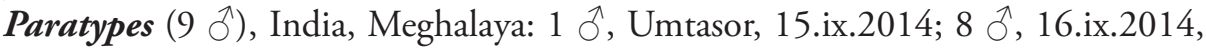
leg. R. Ranjan (Coll. NZCZSI).

Etymology. The species is named after its type locality Umtasor, Meghalaya, India.

\section{Sacada pallescens Hampson, 1896}

Figs 12, 13, 31, 32

Sacada pallescens Hampson 1896: 171.

Description. Male, wingspan $32 \mathrm{~mm}$ (Figs 12, 13). Pale rufous. Forewing speckled fuscous; a dark brownish basal spot; antemedial line smoothly curved; a speck on discocellular; postmedial line slightly curved below costa, then oblique to inner margin, some fuscous suffusion beyond it; cilia dark at tips; underside ochreous with rufous suffusion on basal half of costa, curved postmedial line present. Hindwing pale with indistinct, evenly curved postmedial line, crossed by a rufous streak on vein $\mathrm{Cu}_{2}$. Underside with curved postmedial line. Male genitalia (Figs 31, 32). Uncus broad with a fold on lateral side; gnathos well developed, tip hooked; valva simple, without any process; tegumen broad; transtilla broad, forming inverted omega $(\omega)$ shape; juxta short and broad, slightly constricted at apex; saccus long; vinculum U-shaped; aedeagus long, vesica membranous with fine scobination, cornuti absent.

Diagnosis. Sacada pallescens is unmistakable among the species studied due to the smoothly curved antemedial line (highly angled in other Indian species, except in S. unilinealis where it is absent) and hindwing which has a prominent rufous streak on vein $\mathrm{Cu}_{2}$.

Type material examined. Lectotype (Fig. 13): BMNH (E) 1626923, male, Bhutan. 95-37.v.96, Sybrida pallescens Hampson/Sacada pallescens Hampson det. M. Shaffer, 1976.

Other material examined. India, Sikkim: 1 O , Dodak, 24.ix.2014, leg. R. Ranjan

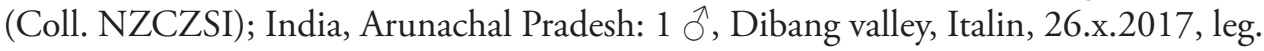
N. Singh (Coll. NZCZSI).

Remark. The lectotype is hereby formally designated. 

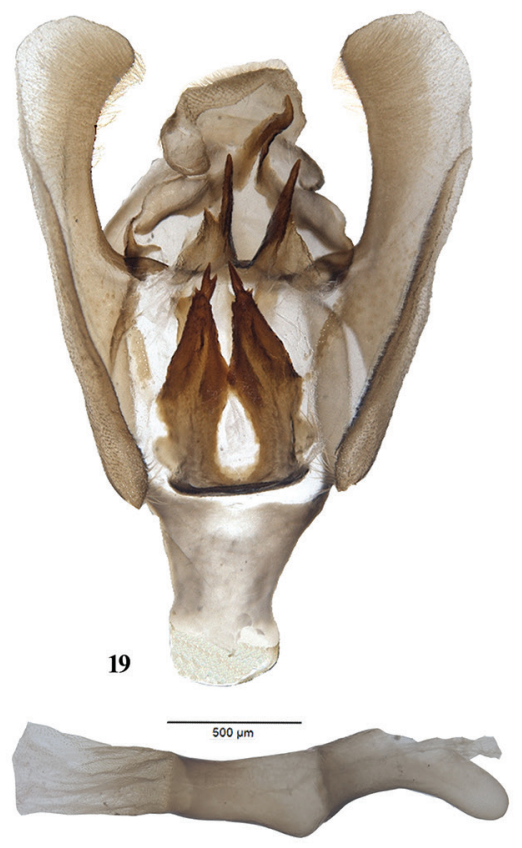

20
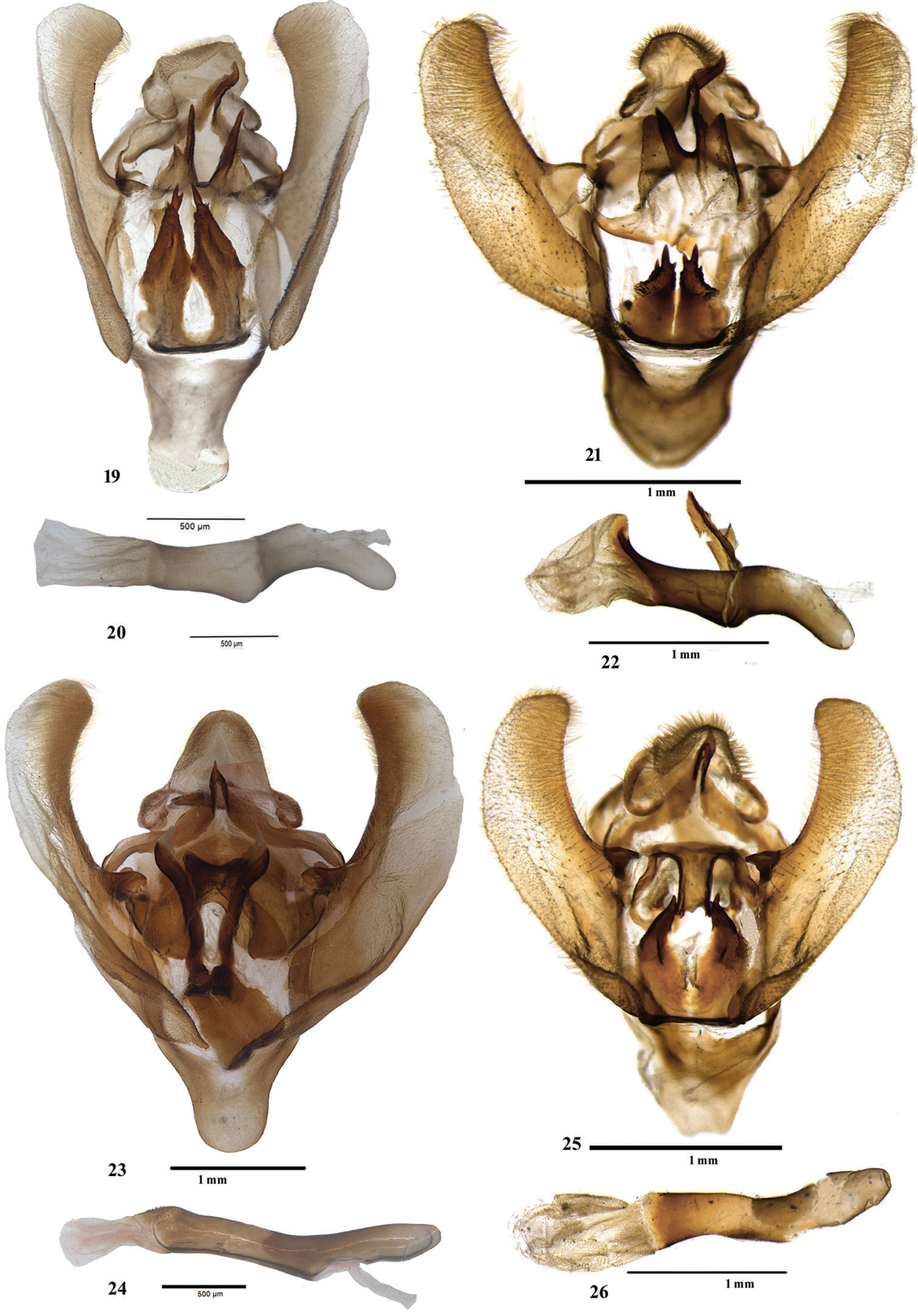

Figures 19-26. Male genitalia of Sacada spp. 19, 20 Male genitalia of S. sikkima (Moore) 21, 22 male genitalia of $S$. constrictalis (Ragonot) 23, 24 male genitalia of $S$. discinota (Moore) 25, 26 male genitalia of $S$. unilinealis Hampson. 


\section{Sacada decora Walker, 1862}

Fig. 14

Sacada decora Walker 1862: 136.

Description. Male, wingspan $25.4 \mathrm{~mm}$ (Fig. 14). Rosy red; forewing with antemedial line outwardly oblique, broadly and inwardly rounded at vein $\mathrm{Cu}_{2}$ to meet inner margin, where a black patch is present towards its inner edge; two black discal spots; an inwardly oblique, paler postmedial line followed by a broad band of fuscous scales, which is diffusing towards termen. Hindwing paler, a diffused postmedial line present.

Diagnosis. Because of the smoothly curved postmedial line (not strongly angled), S. decora is externally similar to $S$. inordinata, $S$. dzonguensis, S. umtasorensis, and $S$. pallescens, but it differs from three of these four species having its hindwing paler, and from $S$. pallescens in having the antemedial line outwardly oblique and broadly and inwardly rounded at vein $\mathrm{Cu}_{2}$.

Material examined. Singapore: hand written slip Sacada decora/BMNH (E) 1626922/1900-276/ H. N. Ridley

\section{Genus Pseudosacada N. Singh, Kirti \& Ranjan, gen. nov.}

http://zoobank.org/42924214-79C7-4293-8591-1E2781DA1D44

Type species. Paravetta flexuosa Snellen, 1890.

Diagnosis. The new genus is morphologically most similar to the genus Sacada and can only be diagnosed on the basis of external male genitalia. In male genitalia, the uncus is broader at base, apically bifid with a shallow constriction. There are two strongly sclerotised processes arising from the latero-medial region of the uncus. The gnathos is long, reaching beyond the uncus, and with its apex having a small hook. The valva is simple and membranous, without any process. The transtilla is broad and with both the edges bearing scorpion's "pedipalp chela"-like sclerotised process. In Sacada, the uncus is hooded, lateral structures are simple, flap-like, and without any horn-like process; the gnathos is short and hardly reaches the hood of the uncus; the valva is thicker; and the transtilla is simple.

Remarks. The type species of the new genus was originally placed in Paravetta (type species Paravetta discinota Moore, 1865). Paravetta is now a synonym of Sacada. However, P. flexuosa is generically distinct from Sacada decora, the type species of Saca$d a$, and therefore a new genus is erected here.

Etymology. The genus is named for its morphological resemblance to some species of Sacada. The gender is feminine.

Distribution. North-eastern India (Meghalaya, Mizoram, Sikkim), southern India (Karnataka); Myanmar; Vietnam; Nepal. 

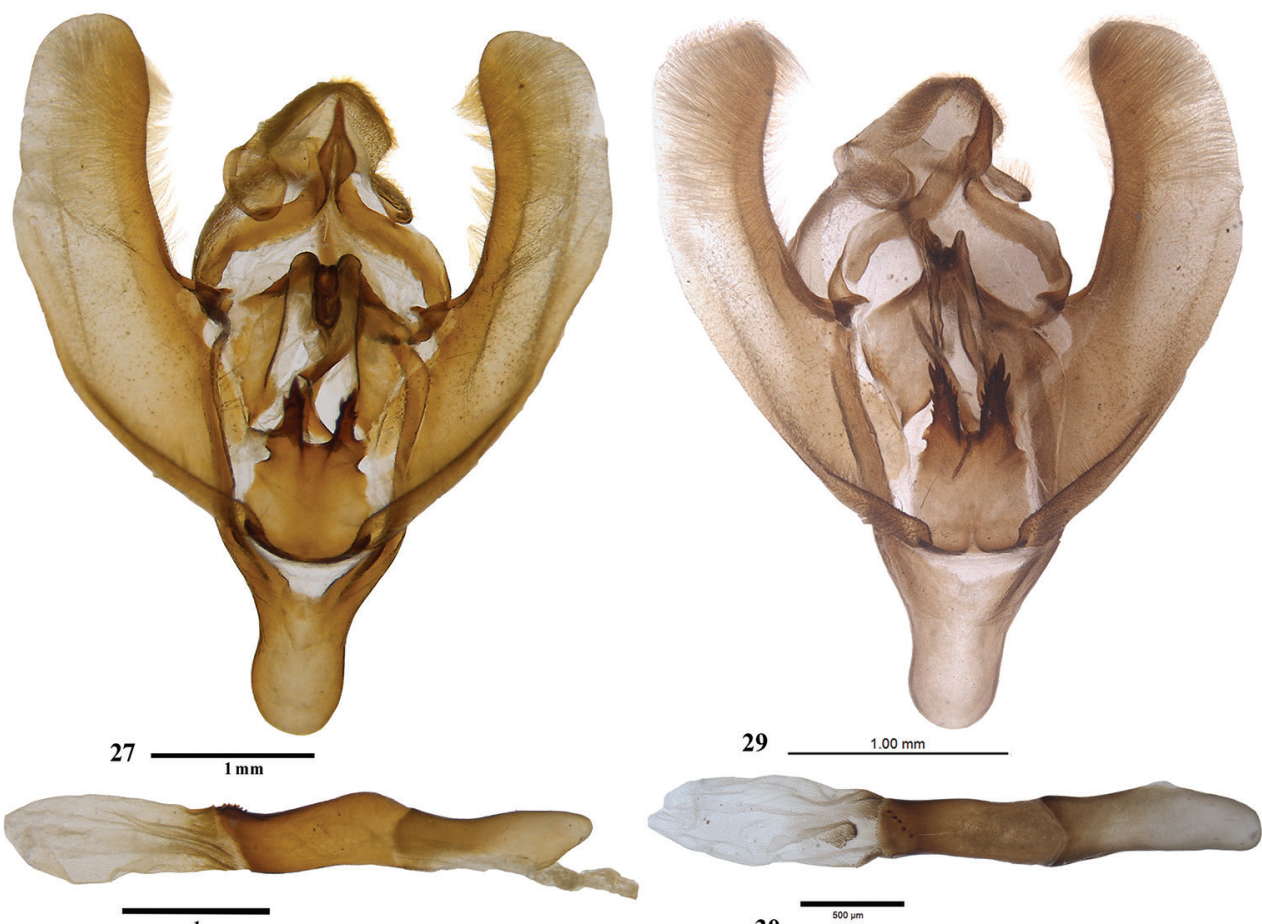

28
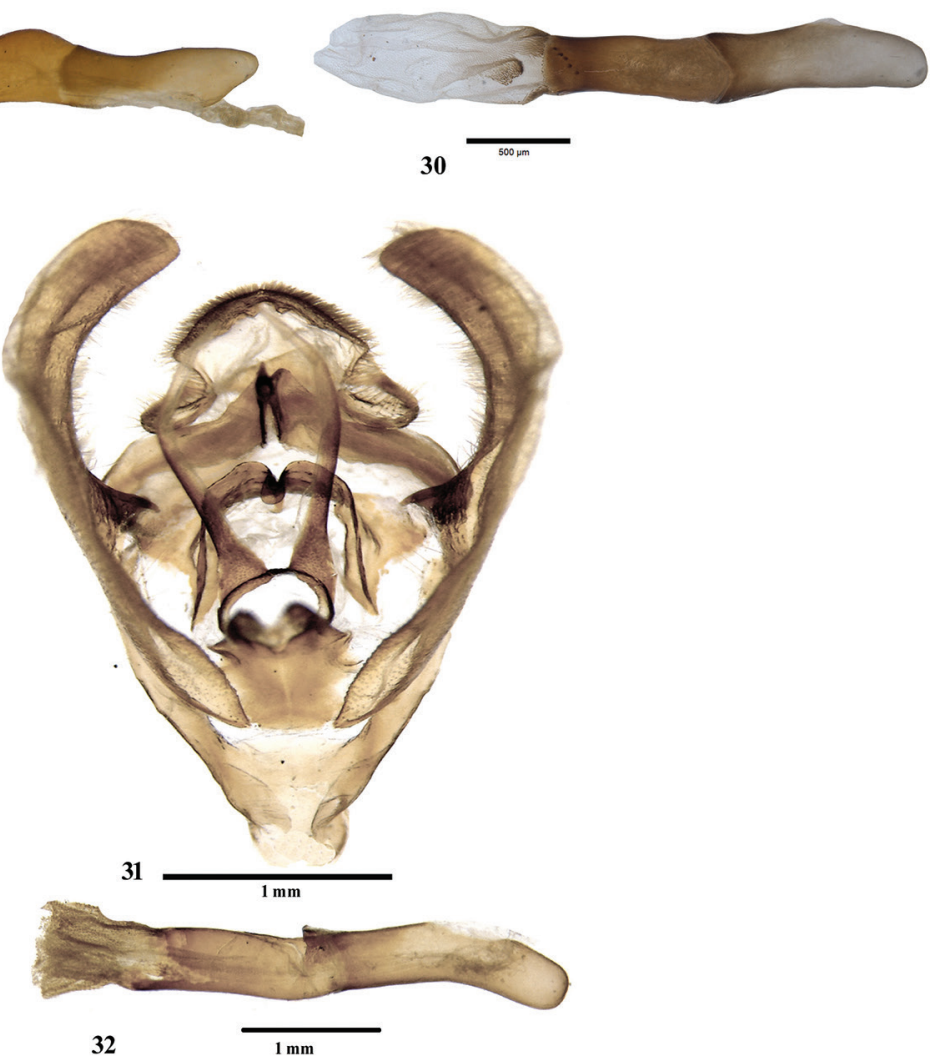

Figures 27-32. Male genitalia of Sacada spp. 27, 28 Male genitalia of $S$. dzonguensis, sp. nov. 29, 30 male genitalia of $S$. umtasorensis, sp. nov. 3I, 32 male genitalia of $S$. pallescens Hampson. 

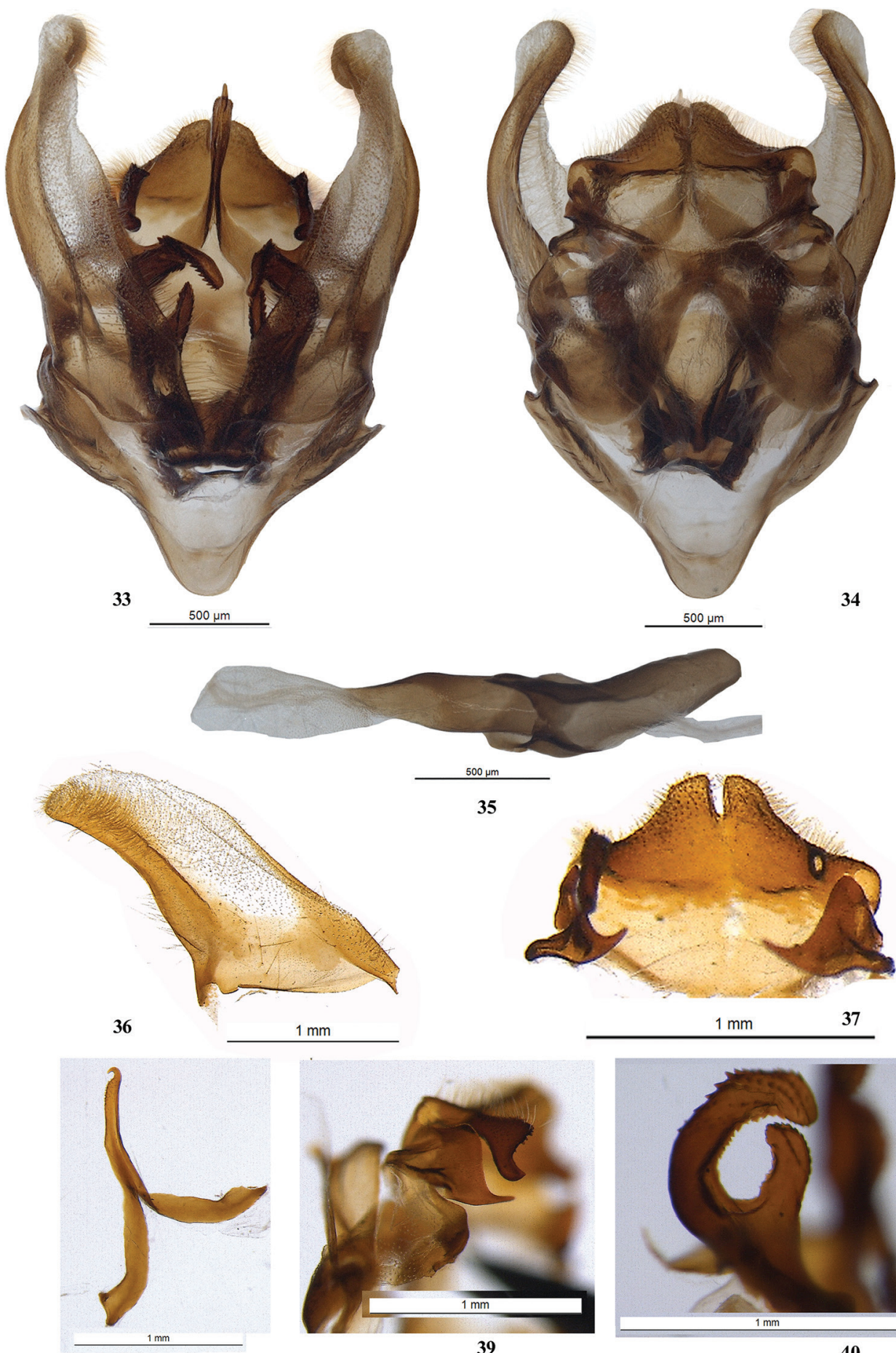

38
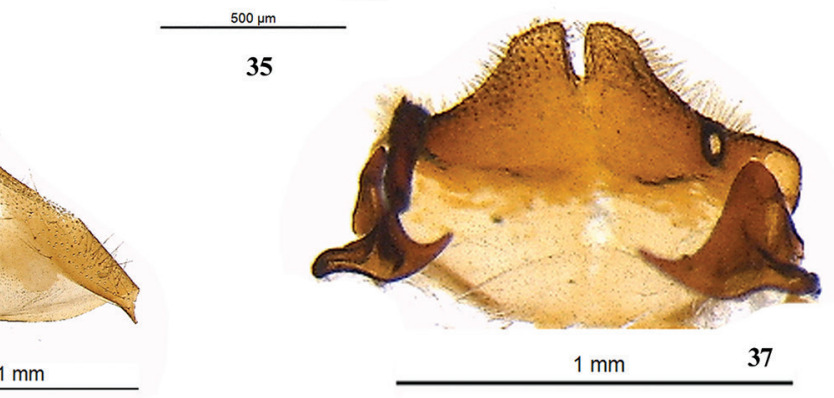

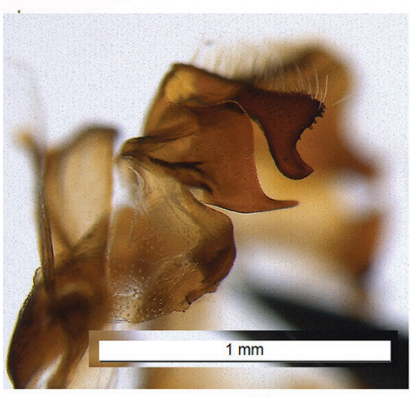

39

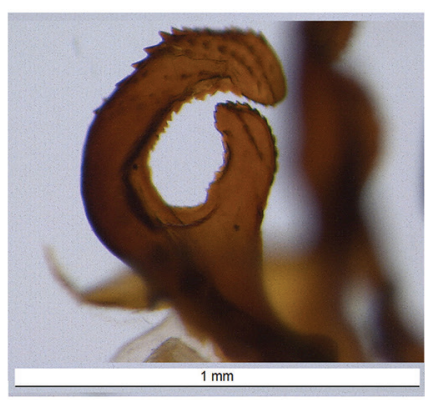

40

Figures 33-40. Male genitalia of Pseudosacada flexuosa (Snellen). 33 Ventral view $\mathbf{3 4}$ dorsal view $\mathbf{3 5}$ aedeagus $\mathbf{3 6}$ valva $\mathbf{3 7}$ uncus $\mathbf{3 8}$ gnathos $\mathbf{3 9}$ lateral process of uncus $\mathbf{4 0}$ enlarged view of transtilla processes. 
Pseudosacada flexuosa (Snellen, 1890), comb. nov.

Figs 15-18, 33-40

Paravetta flexuosa Snellen 1890: 558.

= Sybrida inflammealis Ragonot 1891: 75 .

TD. Lectotype in NHMUK.

Description. Male, wingspan $30 \mathrm{~mm}$ (Figs 15-18). Adult dark chocolate brown with fuscous and purple tinge; antennae bipectinate up to one-third of the length, apically simple; abdomen pale brownish; anal tufts rather strong; forewing with sub-basal, oblique purple patch below cell; antemedial line outwardly oblique from costa to vein $\mathrm{Cu}_{2}$, then rounded inward to meet inner margin, a small indention present in cell; postmedial line inwardly oblique, former inwardly and later outwardly bordered with ochreous scales; area between both lines distinctly differently coloured then rest of wing, an elongate spot on discocellular; on outer side of postmedial line, a roughly rectangular ochreous golden patch present from sub-costa to vein $R_{5}$, veins on it dark. Hindwing ochreous brown with a curved postmedial line; outer area darker; underside paler; cilia as ground colour with fuscous basally. Hind tibia with two pairs of unequal tibial spurs covered with dark rufous scales, tip of each spur covered with whitish scales, one separate bunch of long rufous scales present. Male genitalia (Figs 33-40) discussed under the diagnosis of genus.

Material examined. India, Meghalaya: $6 \hat{\jmath}$, Umtasor, 16.ix.2014, leg. Rahul Ranjan (Coll. NZCZSI); 1 ऽ, Umtasor, 15.ix.2014, leg. Rahul Ranjan (Coll. NZCZSI); 1 กิ, Mawsynram, 28.viii.2014, leg. Rahul Ranjan (Coll. NZCZSI). India, Mizoram: 2 1 , Kanhmun, 15.ix.2016, leg. Rahul Ranjan (Coll. NZCZSI). India, Karnataka: 3 ${ }^{7}$, Ganeshgudi, 28.xi.2013, leg. Rahul Ranjan (Coll. NZCZSI). Fig. 15, Sacada inflamm[e]alis/ Naga Hills, 3000-8000 ft., July-Aug. 1889, W. Doherty/Rothschild Bequest B.M. 1939-1/ BMNH (E) 1627031/ Collectio[n] H. J. Elwes.

Distribution. North-eastern India (Sikkim, Meghalaya, Mizoram, Nagaland), southern India (Karnataka); Vietnam (Yên Bái); Nepal. Records of Mizoram and southern India are newly reported here.

\section{Identification key to the Oriental and Australasian species of Sacada}

$1 \quad$ Hindwing with smoky brown marginal band............................................. 2

- Hindwing without any marginal band .................................................. 3

$2 \quad$ Forewing with antemedial and medial lines well separated ..........S. amoyalis

- $\quad$ Forewing with antemedial and medial lines merged with each other at

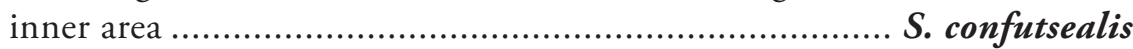

3 Hindwing with postmedial/submarginal line ..........................................10

- Hindwing without any postmedial/submarginal line..................................... 4

$4 \quad$ Forewing with dark spot or white line present.......................................

- $\quad$ Forewing without any dark spot or white line ....................... S. metaxantha

$5 \quad$ Forewing with antemedial and post medial line outlined ........S. ragonotalis

- $\quad$ Forewing with antemedial and postmedial line without any outline............ 6 
Hindwing with postmedial/submarginal line incomplete.

Hindwing with postmedial/submarginal line complete.

Forewing expenses about $20 \mathrm{~mm}( \pm 2-3 \mathrm{~mm})$.

Forewing expenses greater than $30 \mathrm{~mm}$.

Forewing with antemedial and postmedial line fused at inner margin, forming V-shaped figure

Forewing with two specks (separate or joined by a bar)

Hindwing with postmedial line crossed by a rufous streak on vein $\mathrm{Cu}_{2}$

Forewing with a reddish brown discoidal spot defined by grey .... S. papuana

Forewing with a large, fiery red or yellowish rufous patch below the cell before the antemedial line.

23 Forewing with a large yellowish rufous patch below the cell before the antemedial line. 
24 Hindwing whitish, suffused with pale reddish

S. albioculalis Hindwing fuscous; postmedial curved line whitish, area beyond it reddish brown

S. hoenei

25 Forewing with postmedial line highly angled

S. contigua

- $\quad$ Forewing with postmedial line nearly oblique (not angled) .26

26 Forewing with postmedial line oblique from costa to inner margin

S. umtasorensis sp. nov.

- $\quad$ Forewing with postmedial line straight from costa to radial vein and then oblique to inner margin

S. dzonguensis sp. nov.

\section{Discussion}

After the description of two new Sacada species and the transfer of one species to Pseudosacada gen. nov., the genus Sacada now comprises 42 species worldwide, including 23 from the Oriental region and 11 from India. With 13 Sacada species, the Afrotropical region is the next most diverse region for this genus, and a future systematic revision should focus on these species. Apart from this, the Australasian region, with four species (included in the identification key) and the East Palaearctic region with two species (S. fasciata, S. misakiensis) need study to investigate the correct placement of Sacada from these regions based on features of genitalia morphology.

\section{Acknowledgements}

We are thankful to David Lees, curator of Microlepidoptera, NHMUK, for sending the images of Sacada in the NHMUK collection; to the Director, Zoological Survey of India and the Head, Department of Zoology and Environmental Sciences, Punjabi University, Patiala (Punjab), India for providing necessary facilities; to forest officials of the states of North East India and South India (Karnataka) for providing necessary permissions and support to study the pyralin fauna of their respective states. We are grateful to Dr Richard Mally, Czech University of Life Sciences, Prague, Czech Republic, for not only reviewing the manuscript critically but also helping us solve questions raised during its preparation. NS, RR, and KC thank the Ministry of Environment, Forest and Climate Change, New Delhi, Govind Ballabh Pant National Institute of Himalayan Environment and Sustainable Development, and Science and Engineering Research Board, Department of Science and Technology, New Delhi for funding the research.

\section{References}

Bae YS, Byun BK, Paek MK (2008) Pyralid moths of Korea (Lepidoptera, Pyraloidea). Korea National Arboretum, Seoul, 426 pp. 
Butler AG (1878) Descriptions of several new species of heterocerous Lepidoptera from Japan. The Entomologist's Monthly Magazine London 14: 206.

Caradja AV (1925) Ueber Chinas Pyraliden, Tortriciden, Tineiden nebst kurze Betrachtungen, zu denen das Studium dieser Fauna Veranlassung gibt (eine biogeographische Skizze). Memoriile Sectiunii Stiintifice. Academia Romana (ser. 3) Bucuresti 3(7): 257-383.

Caradja AV, Meyrick E (1937) Materialien zu einer Mikrolepidopterenfauna des Yülingshanmassivs (Provinz Yünnan). Deutsche entomologische Zeitschrift Iris 51(4): 137-182.

Evenhuis NL (2020) The insect and spider collections of the world website. http://hbs.bishopmuseum.org/codens/ [Accessed on: 2020-06-22]

Hampson GF (1896) The fauna of British India including Ceylon and Burma. Moths (Vol. 1) Taylor and Francis Ltd. London, 594 pp.

Hampson GF (1906) On new Thyrididae and Pyralidae. Annals and Magazine of Natural History, including Zoology, Botany and Geology (series 7) 17: 112-147, 189-222, 253-269, 344-359. https://doi.org/10.1080/00222930608562536

Hampson GF (1917) Descriptions of new Pyralidae of the subfamilies Epipaschiinae, Chrysauginae, Endotrichinae, and Pyralinae. Annals and Magazine of Natural History, including Zoology, Botany and Geology (series 8) 19: 65-100. https://doi. org/10.1080/00222931709486913

Hering E (1901) Uebersicht der Sumatra-Pyralidae. Stettiner Entomologische Zeitung 62: 13-118, 219-348.

Holland WJ (1900) The Lepidoptera of Buru. Part II. Heterocera. Novitates Zoologicae 7: 555-591. https://doi.org/10.5962/bhl.part.17458

Joannis Jde (1930) Lépidoptères hétérocères du Tonkin. $3^{\mathrm{e}}$ partie. Annales de la Société Entomologique de France 98: 559-834.

Latreille PA (1809) Genera Crustaceorum et Insectorum, Amand Koenig, Parisiis etArgentorati: $1-399$.

Leech JH (1888) On the Lepidoptera of Japan and Corea. Part II. Heterocera, Sect. I. Proceedings of the General Meetings for Scientific Business of the Zoological Society of London 1888: 580-655. [pls 30-32] https://doi.org/10.1111/j.1469-7998.1888.tb06736.x

Leech JH, South R (1901) Lepidoptera Heterocera from China, Japan, and Corea. Part V. Transactions of the Entomological Society of London, 385-514. [pls 14, 15] https://doi. org/10.1111/j.1365-2311.1901.tb01371.x

Leraut PJA (2013) Espèces et genres nouveaux de Pyralinae (Lepidoptera, Pyraloidea, Pyralidae). Bulletin de la Société entomologique de France 118(1): 41-72.

Meyrick E (1930-1936) Exotic Microlepidoptera. Taylor and Francis, London, 642 pp.

Meyrick E (1936-1937) Exotic Microlepidoptera. Taylor and Francis, London, 160 pp.

Meyrick E (1938) New Javanese Lepidoptera. Deutsche Entomologische Zeitschrift Iris 52(2): 73-88.

Moore F (1865) On the lepidopterous insects of Bengal. Proceedings of the General Meetings for Scientific Business of the Zoological Society of London 1865: 755-823. https://doi. org/10.1111/j.1469-7998.1865.tb02432.x

Moore F (1879) Descriptions of Indian Heterocera from the collection of the late Mr W. S. Atkinson. In: Hewitson WC, Moore F (Eds) Descriptions of new Indian lepidopterous in- 
sects from the collection of the late $\mathrm{Mr}$ W. S. Atkinson, with an introductory notice, by Arthur Grote 1. The Asiatic Society of Bengal, Taylor \& Francis, Calcutta \& London, 5-88. Nuss M, Landry B, Mally R, Vegliante F, Tränkner A, Bauer F, Hayden J, Segerer A, Schouten R, Li H, Trofimova T, Solis MA, De Prins J, Speidel W (2003-2020) Global Information System on Pyraloidea. http://www.pyraloidea.org [Accessed on : 2020-6-22]

Ragonot EL (1891) Essai sur la classification des Pyralites (suite). Annales de la Société Entomologique de France 60(1): 15-114.

Robinson GS, Tuck KR, Shaffer M (1994) A Field Guide to the Smaller Moths of South-East Asia. Malaysian Nature Society, Kuala Lumpur, 309 pp.

Roepke W (1938) Ueber indomalayische Lepidoptera Heterocera des Kön. Museums für Naturkunde in Brüssel. Bulletin du Musée royal d'histoire naturelle de Belgique 14(13): 1-72. Roepke W (1943-1944) Remarks on new or little known Indomalayan moths (Lepid. Heteroc.). Natuurhistorisch Maandblad 32(9, 10): 9: 80; 10: 88.

Shibuya J (1928) The systematic study on the Japanese Pyralinae. Journal of the Faculty of Agriculture, Hokkaido Imperial University 21(4): 149-176.

Snellen PCT (1885) Description d'un nouveau genre de Pyralides. In: Romanoff NM (Ed.) Mémoires sur les Lépidoptères, Tome 2. Imprimerie de M. M. Stassuléwitch, St. Petersburg 7: 195-200.

Snellen PCT (1890) A catalogue of the Pyralidina of Sikkim collected by Henry J. Elwes and the late Otto Möller, with notes by H.J. Elwes. Transactions of the Entomological Society of London: 557-647. [pls 19, 20] https://doi.org/10.1111/j.1365-2311.1890.tb03031.x

Snellen PCT (1892) Bijdrage tot de Kennis der Pyralidina. Tijdschrift voor Entomologie's Gravenhage 35: 152-178. [pl. 10]

Strand E (1915) Einige exotische, insbesondere afrikanische Heterocera. Archiv für Naturgeschichte 81A(2): 129-134.

Sutton S, Barlow H, Whitaker T (2015) A preliminary guide to pyralid moths of Borneo. Vol. 1. Natural History Publications (Borneo), Kota Kinabalu, in association with Southdene Sendirian Berhad, Kuala Lumpur, 89 pp.

Tams WHT (1941) New moths of the family Pyralidae. The Entomologist 74: 193-194.

Viette P (1953) Nouvelles pyrales de Madagascar (Lep. Pyralidae). Bulletin de la Société entomologique de France 58: 130-134.

Walker F (1862) Catalogue of the heterocerous lepidopterous insects collected at Sarawak, in Borneo, by Mr. A. R. Wallace, with descriptions of new species. Journal of the Proceedings of the Linnean Society of London 6: 82-145, 171-198. https://doi. org/10.1111/j.1096-3642.1862.tb00945.x

Walker F (1865) Catalogue of Lepidoptera Heterocera, Seventh Series. List of the Specimens of Lepidopterous Insects in the Collection of the British Museum 32: 323-706.

Yamanaka H (1995) Pyralidae of Nepal, I. In: Haruta T (Ed.) Moths of Nepal, Part 4. Tinea, 14, Supplement 2. Japan Heterocerist's Society, Tokyo, 182-193.

Yamanaka H (1998) Pyralidae of Nepal, II. In: Haruta T (Ed.) Moths of Nepal, Part 5. Tinea, 15, Supplement 1. Japan Heterocerists' Society, Tokyo, 99-193. 